Bangl. J. Vet. Med. (2011). 9(1): 33-41

\title{
EXPERIMENTAL PRODUCTION OF NECROTIC ENTERITIS IN BROILER CHICKENS
}

\author{
M. Asaduzzaman, M. S. Miah, A. Siddika, N. Popy and M. M. Hossain* \\ Department of Pathology, Faculty of Veterinary Science, Bangladesh Agricultural University (BAU), \\ Mymensingh
}

\begin{abstract}
The present study was conducted to isolate and identify the Clostridium perfringens, the etiology of necrotic enteritis (NE) from broiler chickens and experimental production of $\mathrm{NE}$ with this isolate. A total of 50 samples were collected from jejunum of necropsied birds for isolation and identification of $\mathrm{Cl}$. perfringens. Out of 50 samples, only 4 isolates of $\mathrm{Cl}$. perfringens were isolated and identified (prevalence 8\%). In experimental NE, the birds of group A (orally administered with only $0.1 \mathrm{ml}$ $\left(1 \times 10^{3}\right.$ sporulated Eimeria acervulina oocysts/bird) showed dullness, ruffled feather, vent feather soiled with bloody faeces after 1 week of coccidial challenge. The birds of group B (orally administered $1 \times 10^{3}$ sporulated Eimeria acervulina oocysts/bird and $1 \mathrm{ml}$ of 2 days old broth culture of $\mathrm{Cl}$. perfringens) showed severe depression, ruffled feathers, bloody faeces with fibrinous cast with $80 \%$ prevalence rate and $30 \%$ mortality in experimental NE. The birds of group C (orally inoculated with $1 \mathrm{ml}$ of 2 days old broth culture of $\mathrm{Cl}$. perfringens) showed no striking clinical, gross and histopathological lesions. Postmortem changes in small intestine (duodenum) were congestion and haemorrhages specially for birds of group A. The most severe gross lesions comprised of ascites, enlarged liver and heart, intestinal distension, profuse haemorrhage, fibrinous cast, fragile intestinal wall and gas bubble formation in the small intestine (duodenum, jejunum and ileum) of birds of group B. Histologically, birds of group B showed hemorrhage and congestion in liver, heart and intestine, desquamation of intestinal epithelium and intense leukocytic infiltration in intestine, liver and heart. The findings obtained from this study showed that simultaneous coccidial infection enhanced the pathological lesions of NE.
\end{abstract}

Key words: $C l$. perfringens, culture, sporulated coccidia, pathogenesis.

\section{INTRODUCTION}

In Bangladesh, among different constrains of poultry industries, outbreak of several devastating diseases is one of the major constraints causing economic loss and discouraging people for poultry rearing (Das et al., 2005; Islam, 2005). Diseases are causing about $30 \%$ mortality of chickens per year. Incidence of the diseases varies depending on the geo-climatic condition, season, breed and age of birds. A survey report on both breeding flocks of commercial broiler and layer in major poultry raising belt in and around Dhaka and Gazipur districts in Bangladesh was conducted by Saleque et.al.(2003) and reported bacterial, viral, mycoplasmal, protozoal, parasitic, fungal and non-infectious diseases as $45 \%, 17 \%, 12.4 \%, 6.6 \%, 4.5 \%, 1.5 \%$ and $12.4 \%$, respectively.

Among bacterial diseases, $\mathrm{NE}$ is one of the most important diseases in poultry that destroys the intestinal lining cells of the digestive tract, occurring outbreaks in broilers from 2-5 weeks of age. It is caused by $\mathrm{Cl}$. perfringens, which is an important pathogen of a wide spectrum of veterinary diseases (McClane et al., 1992). It is considered to be most widely occurring pathogenic bacterium. Clinical signs of this disease include depression, decreased appetite, reduced growth rates, diarrhoea, and severe necrosis of the intestinal tract. Under normal conditions, the bacteria live harmlessly in the gut but when gut microecology is drastically altered $\mathrm{Cl}$. perfringens can proliferate. In its most acute form, NE causes sudden death of many birds within a few hours, without showing any clinical signs of the disease. Mortality is usually between 2-10\% but can be as high as $40-50 \%$ resembling the symptoms of coccidiosis and may be mis-diagnosed. Birds with a milder, sub clinical form of NE may actually cause the cost of the producer more money. These birds may suffer from diarrhoea, appear as depressed and have decreased feed intake. This adversely affects growth rate, feed conversion and uniformity. A diseased bird may be received 30\% less energy and 7\% less protein than a healthy bird (Calnek et al., 1991)

The incidence of necrotic enteritis in Mymensingh district of Bangladesh is 0.60\% (Islam et. al., 1998) and $0.52 \%$ (Talha et. al., 2001). The incidence of necrotic enteritis in Sylhet and Rajshahi Region of Bangladesh is $0.44 \%$ (Islam et. al., 2003) and $0.91 \%$ (Hossain et. al., 2002), respectively.

*Corresponding author e-mail address: mmhossain04@yahoo.com.au

Copyright (C) 2011 Bangladesh Society for Veterinary Medicine

All rights reserved 1729-7893/0220/2011 


\section{Asaduzzaman and others}

Necrotic enteritis is reported by postmortem examination in our country (Islam et. al., 1998, Talha et. al., 2001, Hossain et. al., 2002 and Islam et. al., 2003) but isolation and identification of causal agent in Bangladesh have not been performed. Therefore, the study was undertaken for the isolation and identification of $\mathrm{Cl}$. perfringens from dead or sick bids and experimental pathogenesis study with this local isolate of $\mathrm{Cl}$.perfringens.

\section{MATERIALS AND METHODS}

\section{Collection of samples}

Fifty samples were collected from jejunum of chickens suffering from diarrhoea as well as showing typical postmortem lesions of enteritis from S.K Diagnostic centre, Mymensingh. Intestinal contents from jejunum were collected aseptically in nutrient broth and transported in ice box.

\section{Isolation of $\boldsymbol{C l}$.perfringens}

Sample was first inoculated into nutrient agar stab. For maintenance of anaerobic condition candle jar was used and 1 to $2 \mathrm{~cm}$ layer of sterilized oil (Olive oil) was poured on the surface of the medium (Eyre, 2009). The culture was incubated for $24 \mathrm{hrs}$ at $37^{0} \mathrm{C}$. For determination of hemolytic activity of the organism, the samples from stab culture were spread on blood agar media (sheep blood) and were incubated anaerobically for $24 \mathrm{hrs}$ at $37^{0} \mathrm{C}$. Colonies showing a typical double zone of haemolysis formed in each plate and that was considered as Clostridium organism. For lecithinase test egg yolk emulsion $(0.5 \mathrm{ml})$ was mixed with nutrient broth $(10 \mathrm{ml})$ and $1 \% \mathrm{NaCl}$ was added for clearance of media. The inoculating loop was thrusted with sample to the egg yolk media and was incubated anaerobically for 5 days at $37^{\circ} \mathrm{C}$. A typical opalescent was produced in the media that considered as positive lecithinase test for $\mathrm{Cl}$. perfringens. After that colonies of each isolate were inoculated into TSI (triple sugar iron) agar stab. TSI agar was used to indicate whether $\mathrm{H}_{2} \mathrm{~S}$ had been produced due to the reaction of sulphur containing compounds. Hydrogen sulphide reacted with the ferrous ion of the medium producing ferric sulphide, a black precipitate indicated positive TSI reaction for $\mathrm{H}_{2} \mathrm{~S}$ producing bacteria (Eyre, 2009).

\section{Characterization of $\mathrm{Cl}$. perfringens}

The isolated organisms were identified by their colony morphology, microscopic examination, motility study, enzymatic activity and relevant biochemical tests according to standard laboratory methods (Eyre, 2009).

\section{Maintenance of stock culture}

Nutrient agar slants were used to maintain the stock culture for each of the bacterial isolate. The $\mathrm{Cl}$. perfriengens were inoculated in the slant by streaking and were incubated at $37^{0} \mathrm{C}$ for $24 \mathrm{hrs}$. Finally, glycerol was overlaid and the culture was kept at $-70^{\circ} \mathrm{C}$ (Eyre, 2009).

\section{Cleaning of oocysts}

The duodenal content was collected sacrificing infected broiler chicken. The content was homogenized using stirrer after being collected in $2 \%$ potassium dichromate and kept it for 1 week at room temperature (RT) for sporulation. Then $40 \mathrm{ml}$ of medium was taken in a sterile Falcon tube and centrifuged at $1000 \mathrm{rpm}$ for 15 minutes and supernatant was discarded. After that sediment was washed with PBS (pH 7.4) by centrifugation for three times at $1000 \mathrm{rpm}$ for 15 minutes. Finally, the inoculums were stored at RT (Al-Sheikhly and Al-Saieg, 1980; Baba et al., 1992; Williams et. al., 2003).

\section{Counting of infective dose of oocysts}

$1 \mathrm{ml}$ of coccidial sample was diluted in $9 \mathrm{ml}$ saturated salt $(\mathrm{NaCl})$ solution. A portion of the suspension was withdrawn with the help of plastic transfer pipette and each of the two chambers of McMaster slide was filled with $0.15 \mathrm{ml}$ of suspension. After 3 to 5 minutes oocysts in two chambers were counted by using low power objective (10x). Total oocysts number was calculated by dividing the figure by 0.3 and multiplied by dilution factor 10. Then the concentration of sporulated oocysts was adjusted to $1 \mathrm{X} 10^{3} / 0.1 \mathrm{ml}$ (Baba et al., 1992; Williams et. al., 2003). 


\section{Experimental design}

For the experiment, a total number of 30 broiler birds 2-3 weeks of age (obtained from Trishal poultry farms) were reared for experimental study. They were divided into three groups (A, B and C) (Fig. 1). All group of birds were given commercial pillet feed, adlibitum water with $50 \%$ protein rich fish meal. Each group contained 10 birds. Group A was orally administered with coccidia Eimeria acervulina (1x10 ${ }^{3}$ sporulated oocysts $\left./ 0.1 \mathrm{ml}\right)$, group B for coccidia Eimeria acervulina $1 \times 10^{3}$ sporulated oocysts $/ 0.1 \mathrm{ml} /$ bird $+C l$. perfringens $(1 \mathrm{ml}$ of 2 days old culture broth) and group C (inoculated with $1 \mathrm{ml}$ of 2 days old culture broth of $C l$. perfringens). Experimentally inoculated birds were observed for every 24 hours interval for the observation of effects of different inoculum upto 2 weeks after drenching. In the experimental period mortality rate, necropsy and histopathological findings were recorded.
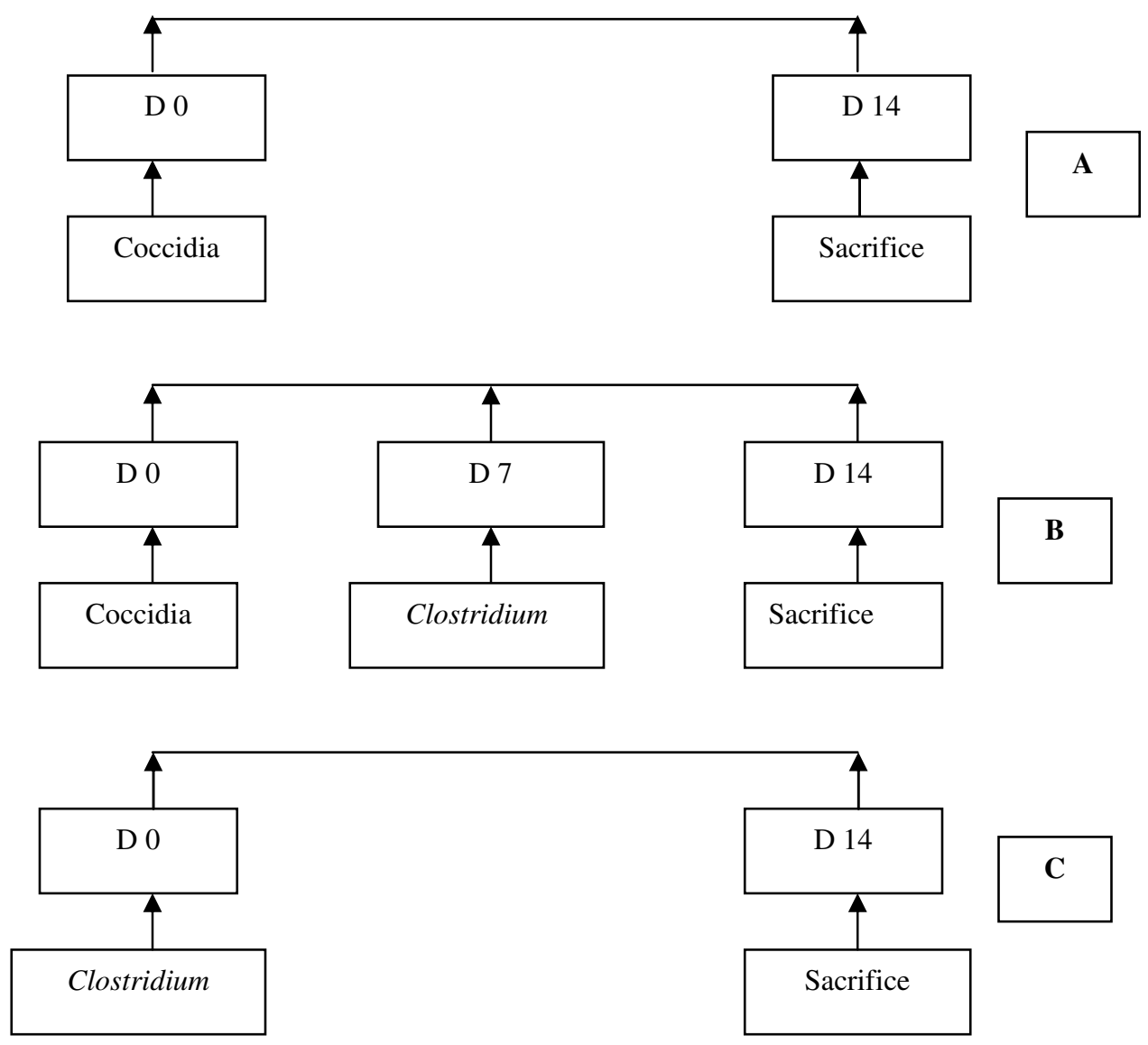

Fig. 1 shows the time schedule for different types of exposure

\section{RESULTS AND DISCUSSION}

Table 1 shows the clinical signs of experimental NE with local isolate of $C l$. perfringens. In this study, the experimental birds were observed for 2 weeks. About $50 \%$ of birds of group A (drenched with only $0.1 \mathrm{ml}$ $\left(1 \times 10^{3}\right.$ sporulated Eimeria acervulina oocysts/bird) showed dullness, ruffled feather, vent feather soiled with bloody faeces after 1 week of coccidial challenge. The clinical signs produced by coccidia recorded in the present investigation corresponded with the findings of others (Al-Sheikhly and Truscott, 1977; Al-Sheikhly and Al-Saieg, 1980; Baba et al., 1992; Williams et. al., 2003; Samad, 2005). A total 80\% of birds of group B (coccidia+Clostridium) showed severe depression, ruffled feathers, bloody faeces with fibrinous cast and 


\section{Asaduzzaman and others}

ultimately died (30\%) 3 days before sacrifice (Table 2). The clinical signs of present investigation reported in birds of group B drenched with E. acervulina $\left(0.1 \mathrm{ml}\left(1 \times 10^{3}\right.\right.$ sporulated oocysts/bird) plus $C l$. perfringens $(1 \mathrm{ml}$ of 2 days old broth) were almost similar by the findings of other investigators (Truscott and Al-sheikhly, 1977; Al-sheikhly and Al- saieg, 1980; Shane et al., 1985; Cowen et al., 1987; Baba et al., 1992; Williams et al., 2003; Van et al., 2004; Drew et al., 2004 and Olkowski et al., 2006). These authors described supply of protein rich feed and simultaneous infection with coccidia might act as predisposing factor for the production of NE. Birds of group $\mathrm{C}$ (inoculated with $1 \mathrm{ml}$ of 2 days old culture broth of $\mathrm{Cl}$. perfringens) did not show any clinical signs.

Table 1. Clinical signs in experimental necrotic enteritis

\begin{tabular}{|c|c|c|}
\hline Group & $\begin{array}{l}\text { Type of } \\
\text { exposure }\end{array}$ & Clinical signs \\
\hline Group A & E. acervulina & Dullness, ruffled feather, vent feather soiled with bloody faeces \\
\hline Group B & E. acervulina & Dullness, ruffled feather, bloody diarrhea mixed with fibrinous cast \\
\hline Group C & $\begin{array}{l}\stackrel{+}{\text { Cl. perfringens }} \\
\text { Cl. perfringens }\end{array}$ & No clinical signs \\
\hline
\end{tabular}

\section{Prevalence and mortality}

In experimental NE, the prevalence rate was $80 \%$ in group $\mathrm{B}$ birds $\left(0.1 \mathrm{ml}\left(1 \times 10^{3}\right.\right.$ sporulated Eimeria acervulina oocysts/bird) plus $\mathrm{Cl}$. perfringens ( $1 \mathrm{ml}$ of 2 days old broth)(Table 2) which were relatively higher than the reports by other authors (Islam et al. 1998; Talha et al. 2001; Hossain et al. 2002; Islam et al. 2003). This is probably due to the fact that other authors diagnosed the diseases mostly based on postmortem examination. No striking clinical signs, mortality, gross and histological lesions were found in birds of group C (inoculated with Clostridium only).

Present study showed $10 \%$ mortality of birds in group A (drenched with only $0.1 \mathrm{ml}\left(1 \times 10^{3}\right.$ sporulated Eimeria acervulina oocysts/bird) while $30 \%$ mortality in birds of group B $\left(0.1 \mathrm{ml}\left(1 \times 10^{3}\right.\right.$ sporulated Eimeria acervulina oocysts/bird) plus $\mathrm{Cl}$. perfringens $1 \mathrm{ml}$ of 2 days old broth) (Table 2). But Shane et al. (1985) observed $35 \%$ mortality (28/80) in birds which received an oral dose of E. acervulina simultaneously with a ration containing $\mathrm{Cl}$. Perfringens but $41 \%$ mortality (33/80) of birds that were fed an inoculated ration two days after an oral dose of E. acervulina and $10 \%$ mortality which were fed an inoculated ration four days after an oral dose of E. acervulina.

Table 2. Prevalence and mortality of birds in experimental necrotic enteritis

\begin{tabular}{|cccccccc|}
\hline Group & Type & $\begin{array}{l}\text { Age } \\
\text { (wks) }\end{array}$ & $\begin{array}{l}\text { No. of } \\
\text { birds }\end{array}$ & $\begin{array}{l}\text { Type of } \\
\text { exposure }\end{array}$ & $\begin{array}{l}\text { No. of birds } \\
\text { clinically ill }\end{array}$ & $\begin{array}{l}\text { Prevalence } \\
\text { rate (\%) }\end{array}$ & $\begin{array}{l}\text { Mortality } \\
\text { rate (\%) }\end{array}$ \\
\hline Group A & & 10 & E. acervulina & 05 & 50 & 10 \\
Group B & Broiler & 2 to 3 & 10 & $\begin{array}{c}\text { E. acervulina } \\
+ \\
\text { Clostridium }\end{array}$ & 08 & 80 & 30 \\
Group C & & 10 & Clostridium & 00 & 00 & 00 \\
\hline
\end{tabular}

\section{Pathology}

Table 3 and 4 describe the gross and microscopic lesions of experimental NE in broiler birds. The birds of group A (drenched with only $0.1 \mathrm{ml}\left(1 \times 10^{3}\right.$ sporulated Eimeria acervulina oocysts/bird) showed severe hemorrhage in the duodenum and jejunum (Fig. 1) while microscopically, showed glandular proliferation in duodenum and jejunum and presence of coccidial merozoites in intestinal epithelium and lamina propria (Fig.s 7-8). 
In present experimental study, the resulted lesions in birds of group $\mathrm{B}\left(0.1 \mathrm{ml}\left(1 \times 10^{3}\right.\right.$ sporulated Eimeria acervulina oocysts/bird) plus $\mathrm{Cl}$. perfringens ( $1 \mathrm{ml}$ of 2 days old broth) were confined to the small intestine (duodenum, jejunum and ileum) which were distended with gas and often friable (Fig.s 3-4). Hemorrhage was also found in small intestine. The main lesion of fibrino-necrotic enteritis always localized in the small intestine either in its entire length or just a segment (duodenum, jejunum or ileum) and characterized by the disappearance of the surface epithelium and necrosis of the villi. Ascites, enlarged liver with accumulation of leukocytes around the central veins (Fig.s 5-6), dilated left ventricle of heart and hemorrhage on all of the heart were found occasionaly. In histopathological study, large numbers of clostridia were seen among the sloughed cells, congestion and hemorrhage were found in lamina propria and foci of coagulation necrosis of the tips of the villi (Fig.s 9-10).

The birds of group C (inoculated with $1 \mathrm{ml}$ of 2 days old culture broth of $C l$. perfringens) did not show any striking lesions grossly (Fig. 2) and microscopically. The gross and histopathological lesions described above in different groups of birds, in the present study, corresponded with the findings of other investigators (Al-Sheikhly and Truscott, 1977; Fukata et al., 1988; Hutchison and Riddell, (1990); Samad, 2005; Keyburn et al., 2008).

Table 3. Gross lesions in experimental necrotic enterits in broilers

\begin{tabular}{|c|c|c|}
\hline Group & Type of exposure & Necropsy findings \\
\hline Group A & E. acervulina & Severe hemorrhage in the duodenum and jejunum \\
\hline Group B & $\begin{array}{l}\text { E. acervulina } \\
\stackrel{+}{+} \\
\text { Cl. perfringens }\end{array}$ & $\begin{array}{l}\text { Ascites, severe hemorrhage in the duodenum and jejunum, blood } \\
\text { mixed with fibrinous mass, gas bubble present in the duodenum, } \\
\text { jejunum and caecum, enlarged liver, hemorrhage on the base of the } \\
\text { heart. }\end{array}$ \\
\hline Group C & Cl. perfrigens & Normal necropsy findings \\
\hline
\end{tabular}

Table 4. Microscopic lesions in experimental necrotic enterits in broilers

\begin{tabular}{|rll|}
\hline Group & Type of exposure & \multicolumn{1}{c|}{ Histopathology } \\
\hline Group A & E. acervulina & $\begin{array}{l}\text { Glandular proliferation in duodenum and jejunum. Presence of coccidial } \\
\text { merozoites in intestinal epithelium and lamina propria. }\end{array}$ \\
Group B & $\begin{array}{l}\text { E. acervulina } \\
+\end{array}$ & $\begin{array}{l}\text { Hemorrhage and congestion in sub mucosa of small intestine (duodenum, } \\
\text { jejunum and ileum). Sloughing of epithelium in small intestine. Hemorrhage } \\
\text { and accumulation of reactive cells also in liver and heart }\end{array}$ \\
$\begin{array}{lll}\text { Group C } \\
\text { (Control) }\end{array}$ & Cl.perfringens & Normal findings \\
\hline
\end{tabular}




\section{Asaduzzaman and others}

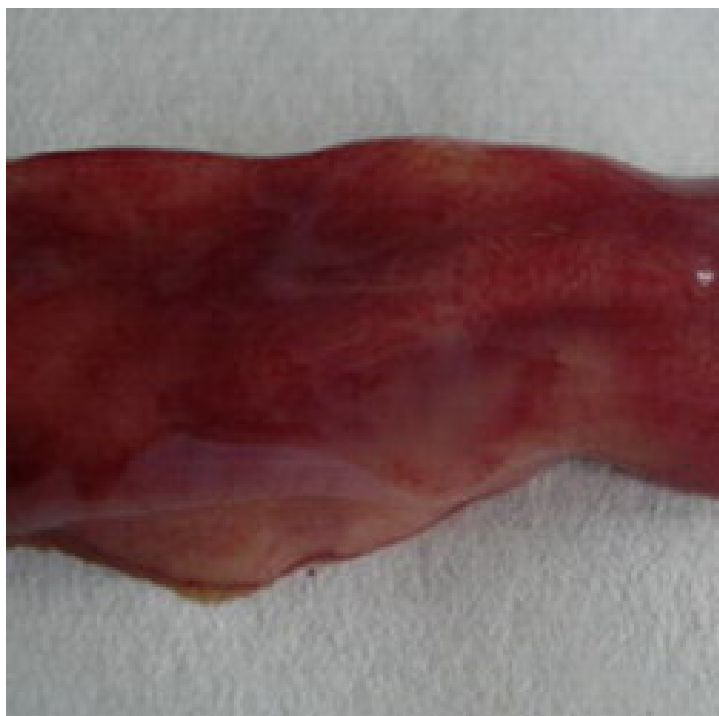

Fig.1 Orally administered group A (coccidia) shows congestion and hemorrhage in the duodenum.

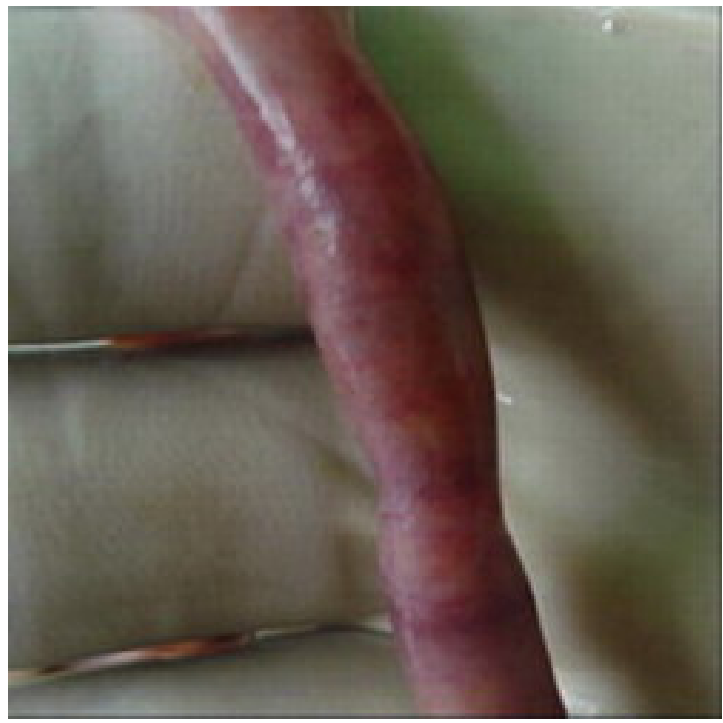

Fig. 3. Orally administered group B (coccidia+Clostridium) shows congestion and distended ileum.

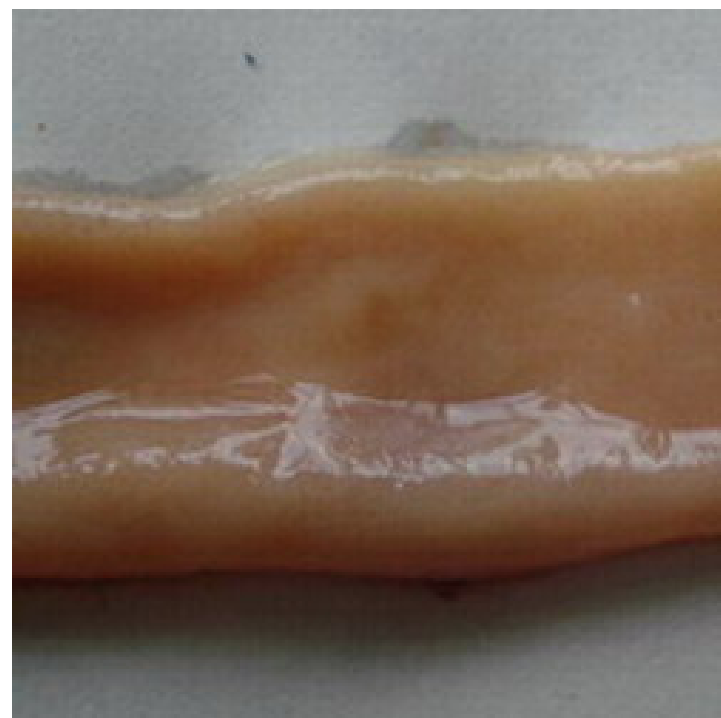

Fig.2 Orally administered group $\mathrm{C}$ (only $\mathrm{Cl}$. perfringens) shows the normal duodenum.

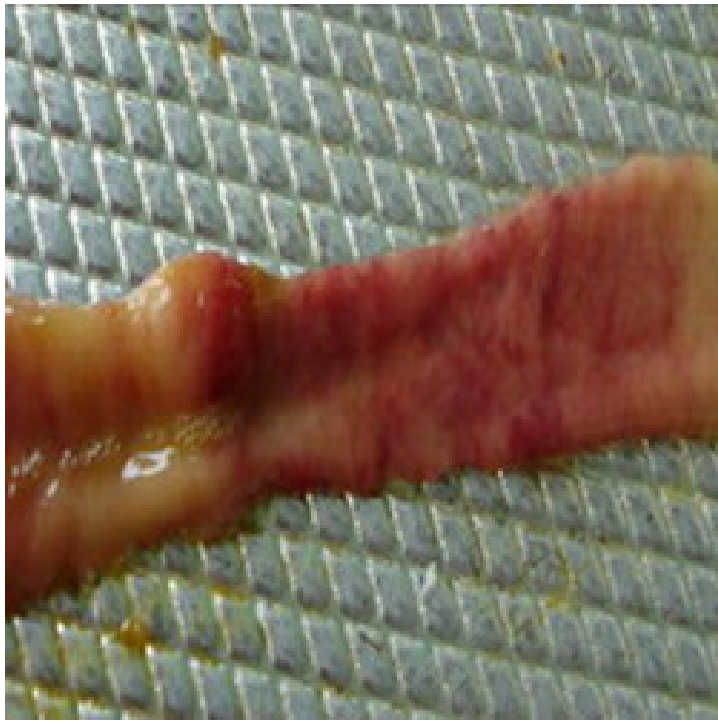

Fig.4. Orally administered group B (coccidia+Clostridium) shows hemorrhage and fibrino-necrotic area in ileum. 


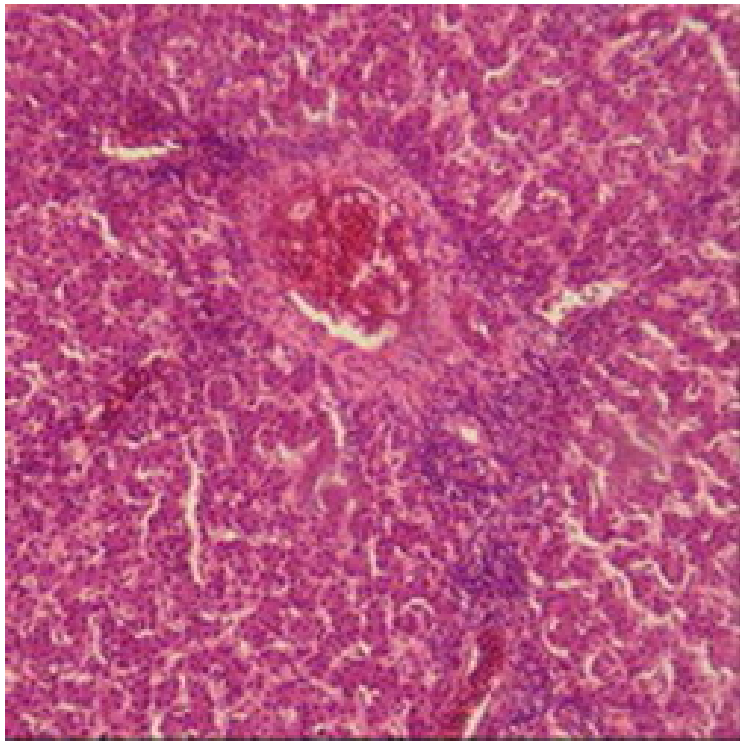

Fig. 5. Orally administered Group B (coccidia + Clostridium) shows congested blood vessels and accumulation of heterophils and lymphocytes in liver (H\&E, x82.5).

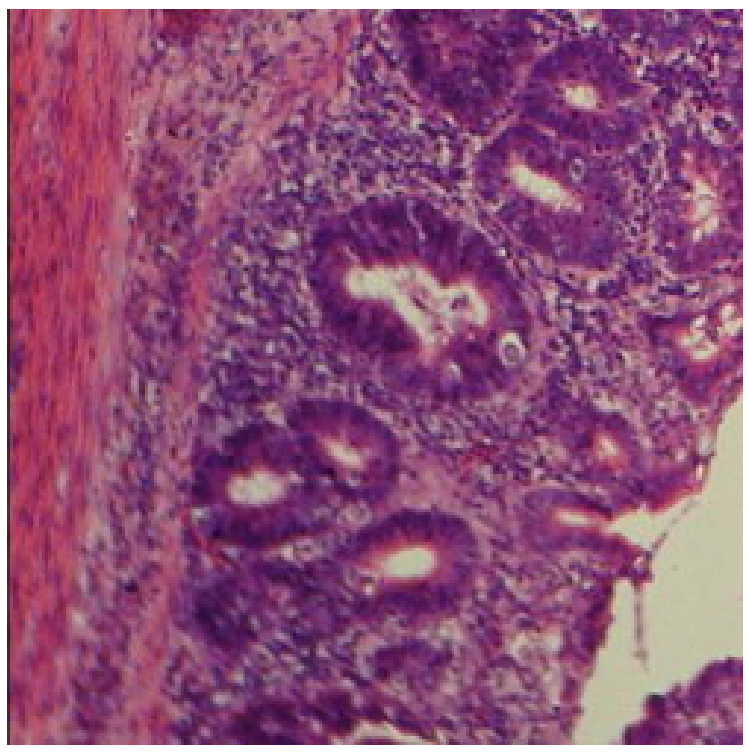

Fig. 7.Orally administered group A (coccidia) shows schizonts (arrow) containing merozoites in jejunal glandular epithelium (H\&E, x330).

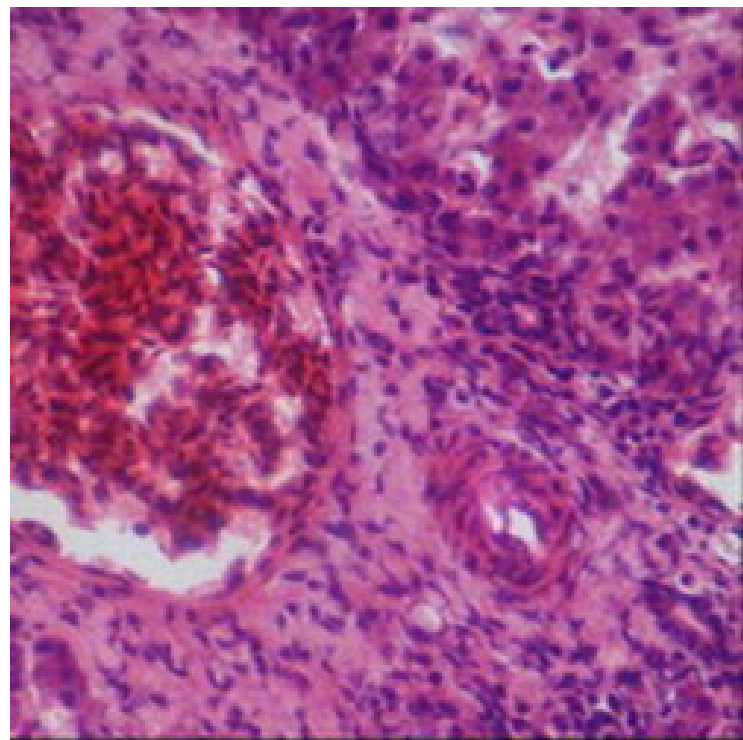

Fig.6. Orally administered Group B (coccidia + Clostridium) shows congested blood vessels and accumulation of heterophils and lymphocytes in liver (H\&E, x330).

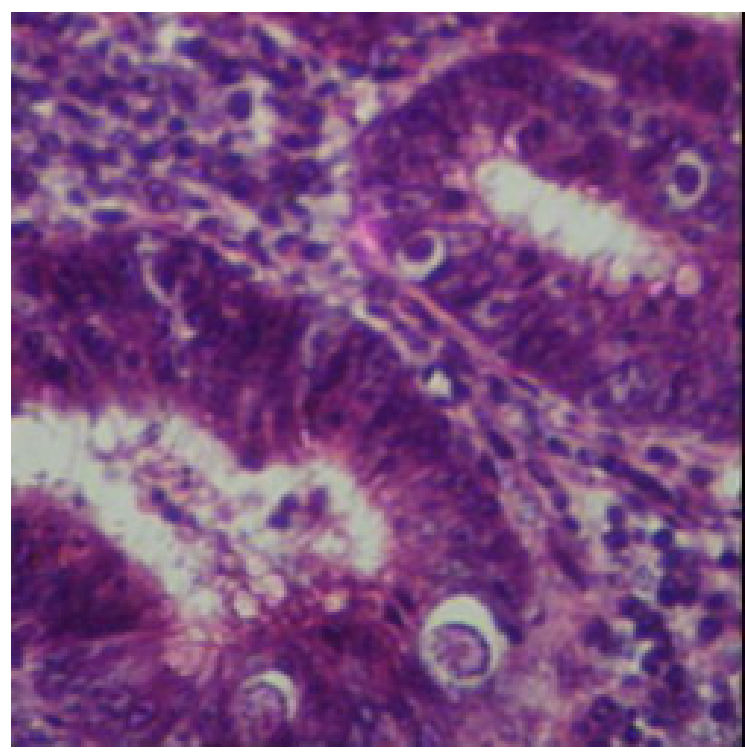

Fig. 8.Orally administered group A (coccidia) shows schizonts (arrow) containing merozoites in jejunal glandular epithelium (H\&E, x825). 

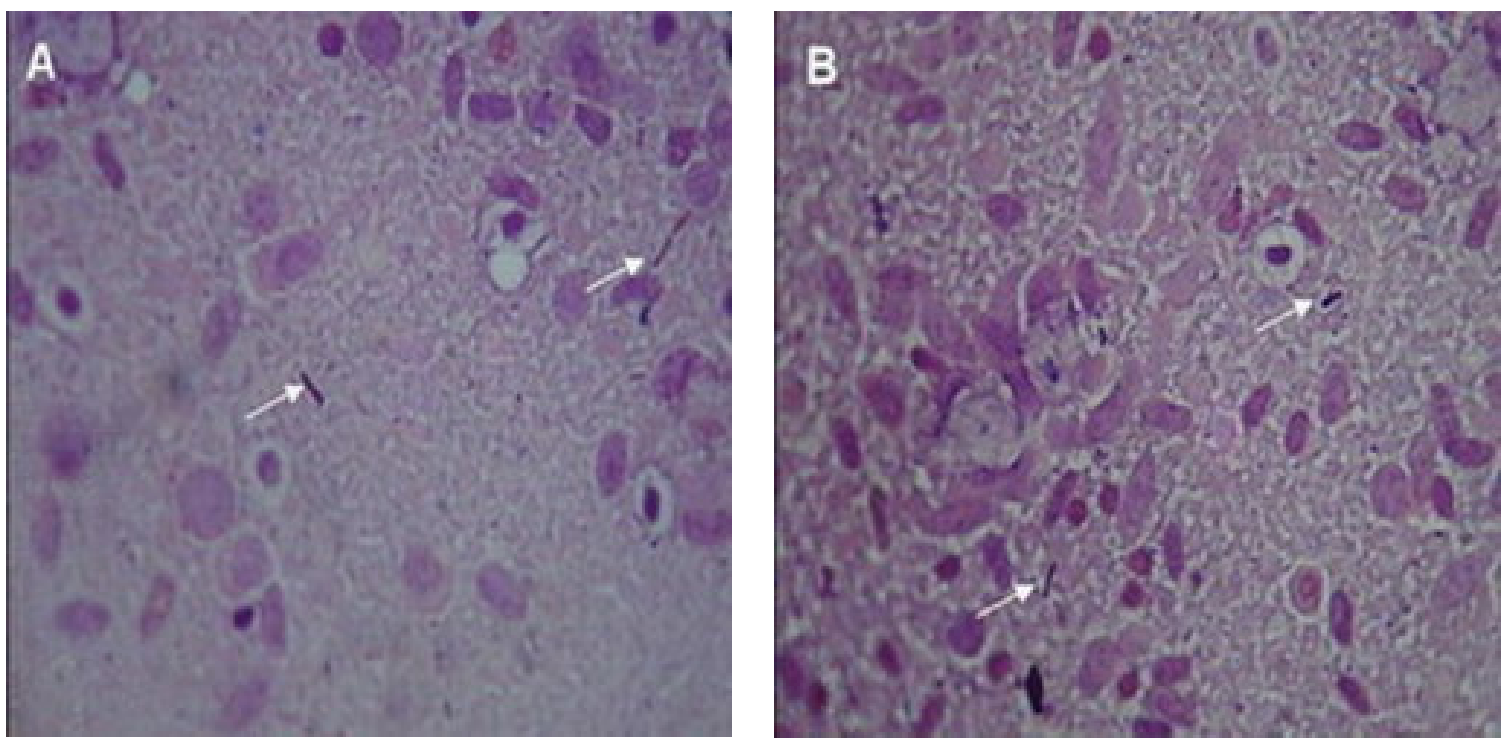

Fig.9. (left) and Fig. 10. (right) Gram's staining of impression smear prepared from jejunum of group B (coccidia+Clostridium) shows Gram positive short rods (arrows, A \& B) of Clostridium sp. (x825)

Clostridium perfringens like organism were successfully isolated and identified from clinically suspected cases of necrotic enteritis. The disease was reproducible in experimentally inoculated broiler when birds were infected with coccidia with one week ahead of experimental clostridial infection.

\section{REFERENCES}

1. Al-Sheikhly F and Truscott RB (1977). The pathology of necrotic enteritis of chickens following infusion of broth cultures of $\mathrm{Cl}$. perfringens into the duodenum. Avian Diseases 21: 230-240.

2. Al-Sheikhly F and Al-Saieg A (1980). Role of coccidia in the occurrence of necrotic enteritis of chickens. Avian Disease 24 (2): 324-33

3. Baba E, Fuller AL, Gilbert JM, Thayer SG and McDougald LR (1992). Effects of Eimeria brunette infection and dietary zinc on experimental induction of necrotic enteritis in broiler chickens. Avian Diseases. 36: 59-62.

4. Clanek BW, Barnes HJ, Beard CW, Mcdougald LR and Saif YM (1991). Diseases of Poultry. $10^{\text {th }}$ edition Iowa State University. Press, Ames, USA. 81-130.

5. Cowen BS, Schwartz LD, Wilson RA and Ambrus SI (1987). Experimentally induced necrotic enteritis in chickens. Avian Diseases 31: 904-906.

6. Das PM, Rajib DMM, Noor M and Islam MR (2005). Retrospective analysis on the proportional incidence of poultry diseases in greater Mymensingh district of Bangladesh. In proceeding of $4^{\text {th }}$ International Poultry Show and Seminar, From February 28 to March 2, 2003, held in Bangladesh China Friendship Conference Centre (BCFCC), Arargaon. 35-39.

7. Drew MD, Syed NA, Goldade BG, Laarveld B and Van Kessel AG (2004). Effects of dietary protein source and level on intestinal populations of $\mathrm{Cl}$. perfringens in broiler chickens. Department of Animal and Poultry Science, University of Saskatchewan, Saskatoon, SK, Canada S7N 5A8.

8. Eyre JWH (2009). The Elements of Bacteriological Technique A Laboratory Guide for Medical, Dental, and Technical Students. ${ }^{\text {nd }}$ edition, press of W. B. Saunders Company Philadelphia. 236-248.

9. Fukata T, Hadate Y, Baba E, Uemura T and Arakawa A (1988). Influence of Cl.perfringens and its toxin in germ-free chickens. Research in Veterinary Science 44: 68-70. 
10. Hossain MK, Ahmed M, Kabir H, Sarker MRR, Jalil MA and Adhikary GN (2002). Poultry diseases at Rajshahi in Bangladesh. Faculty of Veterinary Science, Dinajpur Government Veterinary College.

11. Hutchison TW and Riddell C (1990). A study of hepatic lesions in broiler chickens at processing plants in Saskatchewan. The Canadian Veterinary Journal 31(1): 20-25.

12. Islam MR (2005). Diagnosis of poultry diseases in the aera of molecular biology. In proceeding of $4^{\text {th }}$ International Poultry Show and Seminar, From February 28 to March 2, 2003, held in Bangladesh China Friendship Conference Centre (BCFCC), Agargaon. 18-26.

13. Islam MR, Das BC, Hossain K, Lucky NS and Mostafa MG (2003). A Study on the Occurrence of Poultry Diseases in Sylhet Region of Bangladesh. International Journal of Poultry Science 2(5): 354-356.

14. Islam M, Khan MAHNA, Das PM and Bari ASM (1998). Poultry diseases diagnosed at necropsy in 1997 and 1998 in the Department of Pathology, Bangladesh agricultural University, Mymensingh. Proceedings of $5^{\text {th }}$ BSVER Annual Scientific Conference held on 3-4 Dec. 1998, at Bangladesh Agricultural University, Mymensingh.

15. Keyburn AL, Boyce JD, Vaz P, Bannam TL, Ford ME, Parker D, Di Rubbo A, Rood JI and Moore RJ (2008). NetB, a new toxin that is associated with avian necrotic enteritis caused by $C l$. perfringens. Public Library of Science Pathogens 4(2): 26.

16. McClane BA, Fisher DJ, Sayeed S and Chakrabarti G (1992). The enteric toxins of Cl. perfringens. University of Pittsburgh School of Medicine, Department of Molecular Genetics and Biochemistry, Pittsburgh, PA 15261, USA.

17. Olkowski AA, Wojnarowicz C, Chirino-Trejo M and Drew MD (2006). Responses of broiler chickens orally challenged with $\mathrm{Cl}$. perfringens isolated from field cases of necrotic enteritis. Research in Veterinary Science 81: 99-108.

18. Saleque MA, Rahman MH and Hossain MI (2003). Seasonal variation in the prevalence of poultry diseases in Bangladesh. ${ }^{\text {th }}$ BSVER Annual Scientific Conference held at BAU, Mymensingh on 6-7 January, BSVER Publication 24: 23-24.

19. Samad MA (2005). Poultry Science and Medicine. LEP publication No. 10, Lyric-Epic prokasoni Bangladesh Agricultural University campus, Mymensingh. 537-538.

20. Shane SM, Gyimah JE, HarringtonKS and Snider TG (1985). Etiology and pathogenesis of necrotic enteritis. Journal of Veterinary Research Communication 9(1): 269-287.

21. Talha AFSM, Hossain MM, Chowdhury EH, Bari ASM, Islam MR and Das PM (2001). Poultry Diseases occurring in Mymensingh District of Bangladesh. The Bangladesh Veterinary Journal 18: 20-23.

22. Truscott RB and Al-Sheikhly F (1977). Reproduction and treatment of necrotic enteritis in broilers. American Journal of Vetetrinary Research. 38(6): 857-61.

23. Van IF, De Buck J, Pasmans F, Huyghebaert G, Haesebrouck F and Ducatelle R (2004). Cl. perfringens in poultry: an emerging threat for animal and public health. Avian Pathology 33(6): 537-549.

24. Williams RB, Marshall RN, La Ragione RM and Catchpole J (2003). A new method for the experimental production of necrotic enteritis and its use for studies on the relationships between necrotic enteritis, coccidiosis and anticoccidial vaccination of chickens. Parasitology Research 90 (1): 19-26. 